\title{
Website Effectiveness as Promotion Media Attractions in North Sulawesi
}

\author{
Stephy B. Walukow \\ Electrical Engineering \\ Manado State Polytechnic
}

\author{
Edwin S.A. Lumunon \\ Electrical Engineering \\ Manado State Polytechnic
}

\author{
Toban T. Pairunan \\ Electrical Engineering \\ Manado State Polytechnic
}

\author{
Sonny R. Kasenda \\ Electrical Engineering \\ Manado State Polytechnic
}

\begin{abstract}
The use of electronic media today is a great opportunity for the business world. Electronic media is the best promotional tool used to promote tourism objects. Promotion through electronic media is used by the government and tourism area managers to attract tourists to visit tourist attraction.

The Budo Village, located in Wori District, North Minahasa Regency, has a mangrove forest which is one of the tourism sectors in the North Sulawesi area. Budo Village has excellent potential to increase the tourism sector in North Minahasa. However, the current problem is that Budo Village is not yet known to many people who visit Manado City. Therefore, the purpose of this study is to promote Budo Village through the media website and to test the effectiveness of the website through analysis of respondents. This study uses a descriptive qualitative research model and interviews with respondents who have used the website. According to $88.2 \%$ of respondents, every tourist attraction must have a website page for promotion. Therefore, researchers use the website as a medium to promote Budo Village, by displaying information in the form of photos, videos of the location of Budo Village tourist attractions.
\end{abstract}

\section{Keywords}

Desa Budo, Promotion, Website, Effectiveness

\section{INTRODUCTION}

North Sulawesi experienced a decline in revenue in the tourism sector starting in 2020 when the Covid-19 Pandemic swept across the world. In fact, North Sulawesi is known as one of the provinces that has many beautiful tourist attractions and is recommended to visit. Having hilly land contours and many beautiful beaches make this area enriched with various interesting natural attractions. One of the locations that is not well known to the wider community in the North Sulawesi Province is the Budo Village mangrove tourism located in Wori District, North Minahasa Regency. The people of Budo Village believe that mangrove tourism in this village is no less beautiful than the Bunaken Marine Park. This seaside recreation area is being developed into a tourist center in Wori District. Budo Village has an area of about 423 hectares with boundaries: to the north it is bordered by the Sulawesi Sea, to the south by the Talawaan Bantik Village, to the west by the Sulawesi Sea and to Minaesa Village.

The promotion and marketing system for the tourism potential of Budo Village is currently not managed optimally and does not have online promotion services, so it is less well known to the wider community. To promote a tourist attraction area, tourist attraction becomes an inseparable part in the marketing process because it will make it easier for marketers to influence the perception of potential tourists. Kotler and Armstrong (2008) state four important variables in marketing called the 4Ps, namely product, price, promotion, and place. Of the four variables, promotion is a variable that greatly influences the course of a tourist area, this is also stated by Betari CA et al (2016) who asserts that promotional activities are one of the stages of marketing activities that have an important role in increasing tourist visits in an area. tourist area [1]. In addition, in a study conducted by Kartika et al (2018), the strategy of developing tourist attraction can be optimized for tourism activities and promotions [2].

There are two types of promotional media that can be chosen by the tourism area management community, namely conventional media or online media. Utami et al (2011) in their research stated that of the two types of promotional media, online media is a very good medium in promoting a product or tourist area at a time of rapid technological development today [3]. Meanwhile, according to the results of research from Wilopo and Hakim (2017), it is stated in the results of the study that the strategy for developing tourist destinations can be done, among others, by compiling tour packages, developing destination images, developing print and online promotions, participating in activity events, accessibility, amenities, facilities. and human resource management [4]. In the research of Kondoj and Langi (2017), it is concluded that to increase competitive advantage in promotion, it requires a computerized and well-integrated system. Therefore, Information Systems can provide solutions in terms of promotion [5]. Based on the results of several studies, it can be concluded that the promotion strategy for developing aspects of tourist attraction must be developed and its development must be published so that it can be seen by the public. Therefore, with the current Pandemic conditions that allow the use of mobile mobility by the community to increase in this era of the covid -19 pandemic, this could be the answer for the Budo Village tourism sector to take advantage of it. Indonesia has a population growth that accesses the internet by $17 \%$ in the last year. This figure is equal to 25.3 million new internet accesses in a year [6]. Therefore, this research aims to test the effectiveness of the website in promoting tourism in this case a case study in Budo Village using descriptive qualitative methods and interviews with respondents.

Some of the formulation of the problem in this study are as 
follows:

Conducting interviews related to tourism promotion media.

- Information system design

- Develop a website page for the promotion of the potential and tourist attraction of Budo Village.

In this study, interviews were conducted with 144 respondents through a questionnaire using google form with respondents aged 15-55 years. System development, designed with 2 main parts, namely the main website display page and the administrator page. The website is designed using the database MySQL and framework .

The variables observed in this research are the structure and semantics of the information generated. gutter.

\section{LITERATURE REVIEW}

\subsection{Information System}

Understanding the system is a collection of people who work together with the provisions of the rules that are systematic and structured to form a single unit carrying out a function to achieve goals. The system has several characteristics or properties consisting of system components, system boundaries, the environment outside the system, system liaisons, system inputs, system outputs, system processing and system targets. While the definition of information is data that is processed to be more useful and meaningful for the recipient and to reduce uncertainty in the decision-making process regarding a situation. An information system is a combination of people, hardware, software, communication networks, data sources, policies, and procedures that store, retrieve, transform, and distribute information within an organization[7]. According to Ralph Stair and George Reynolds, Information System is a collection of various elements that collect, manipulate, store, and even disseminate data and information to achieve a goal. [8].

\subsection{Marketing Information System}

Marketing Information System is a computer-based system that can be connected with other information systems to solve problems related to marketing products [9]. Marketing Information System is a system that supports all marketing activities within a company by utilizing various technologies to provide product marketing information to those who need the information. This system provides various information for sales activities, product promotions, and all activities related to marketing.

\subsection{Website}

Website is a collection of pages to display various kinds of information in the form of text, images either still or motion, animation, sound and or a combination of all of them that are interrelated and connected to page networks[10]. In developing a tourism promotion website, website design is a design to process data about tourist objects that can be accessed directly by visitors. This system also aims to produce various information on interesting tourist objects, facilities available at tourist attractions, products produced, and so on. This system can also help make it easier for tourists to recognize and disseminate tourist attraction information widely. The functions of developing a tourism promotion and marketing website include :

1. Development of Tourist Attractions and Attractions

2. Improve and Develop promotion and marketing media.

\subsection{Content Management System (CMS)}

CMS (Content Management System) is software that is created and used to add, change and even manipulate website content. With CMS, a website administrator can manage the types of various files such as text, audio, video, documents and all types of files that can be displayed on the website [11]. Definition of Content Management System (CMS) - Content Management System or often referred to as CMS is a website application that contains templates to easily manage the contents of web pages. The use of a Content Management System does not require reliable web programming knowledge because the installation process and how to use it are user friendly.

\subsection{Secure Socket Layer (SSL)}

SSL (Secure Socket Layer) is a way for a website to establish a secure (encrypted) connection between a web server (website) and a client (Browser) or between a mail server and a mail client. So that the connection between the client and server can run safely from other parties who are not interested [12]. The website server must have an SSL certificate before it can establish an SSL connection. When someone activates the SSL protocol on their website server, they are asked to answer questions that will establish their identity. The question asks for information about both the site and the company. After the SSL certificate is requested, the website server creates two cryptographic keys, namely the Public Key and the Private Key.

\subsection{Rapid Application Development(RAD)}

Rapid Application Development (RAD) or rapid application development, proposed by Kendall is an object-oriented approach to system development that includes development methods as well as software. Kendall sees RAD as a systems development methodology that seeks to address changing user requirements and recommends RAD for developing webbased applications. According to Pressman, RAD is a soft process model that emphasizes a short development life cycle. Meanwhile, according to $\mathrm{Sch}$ ach, a rapid prototype model is a working model where most of the functional applications are already running [13].

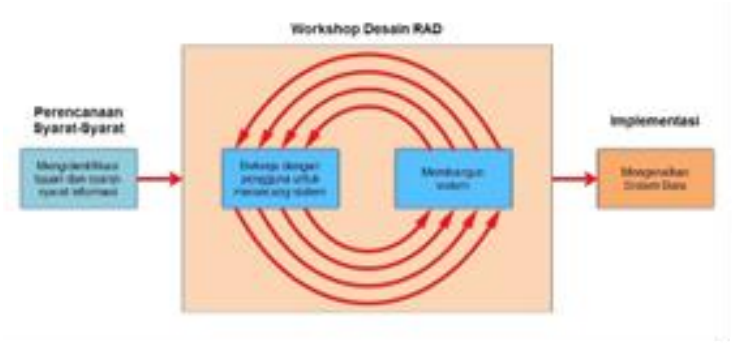

Figure 1. Rapid Application Development (RAD)

\section{RESEARCH METHOD}

The research procedure is a framework in the form of steps in the implementation of research. Data were collected by interview method, by limiting the age of the respondents, namely $15-55$ years and a total of 144 respondents. As for the data generated, $97.9 \%$ of respondents have ever accessed the website. The framework used uses the RAD methodological approach so that it consists of the requirements analysis stage, the RAD Design Workshop (Modeling) stage, and the Implementation (Construction) stage. There are two parts of the analysis carried out in this study, analysis of requirements for analysis of interviews and observations of respondents while modeling analysis is related to analysis of systems that will support the effectiveness of the website that will be developed as a promotional media. 


\subsection{Requirements Analysis}

The results of interviews and observations made to the public regarding the effectiveness of the website as a medium for promoting tourism objects in North Sulawesi. Currently there is no website that introduces tourist attractions other than the official website of the tourism office.

\subsection{Analysis Modeling}

This stage has the aim of analyzing all activities in the overall system architecture by involving the identification and description of the underlying software system abstractions and their relationships. The conceptual framework of the design can be seen in figure 2 .

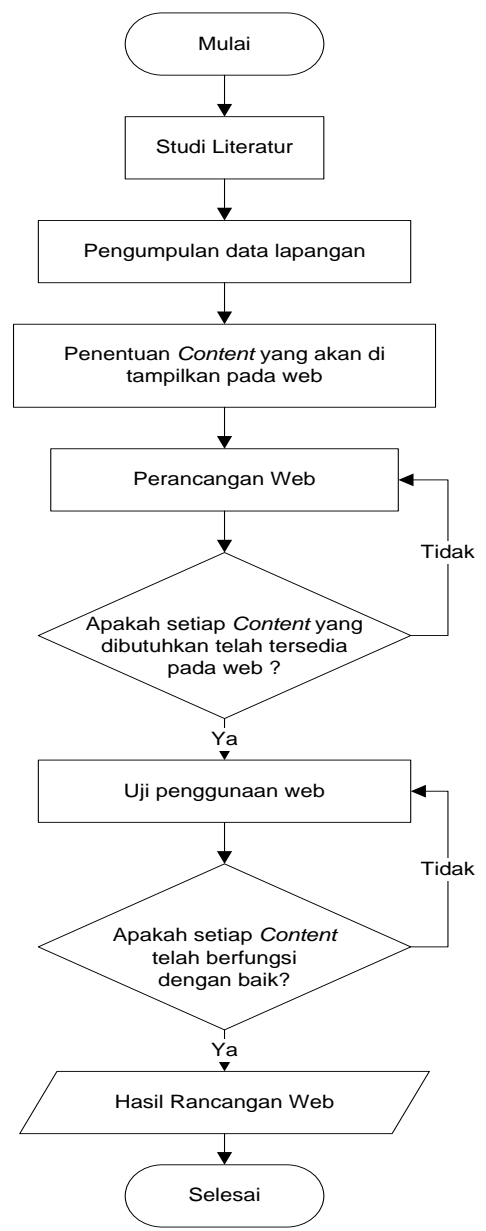

Figure 2. Conceptual Framework

\section{RESULTS AND DISCUSSION}

The initial question of the questionnaire is how to get information about a tourist attraction, the result obtained is :

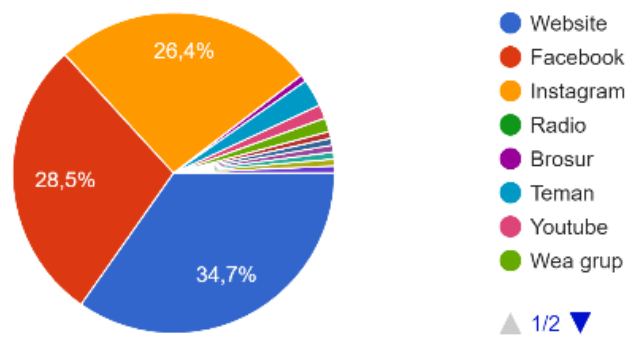

Figure 3 Questionnaire Result

By using the interview method to obtain data and information about the most effective promotional tools that are widely used by the public, as well as what online promotion media are widely known and easily accessible. The number of respondents who participated in filling out the google form was 144 respondents, dominated by respondents aged 18 years as much as $22.9 \%$ and 19 years as many as $20.8 \%, 34.7$ respondents still use the website as a means to find tourist attraction information.

Respondents' addresses consisted of Manado, North Minahasa, Minahasa, Bitung, Minsel, Tomohon, South Minahasa, Sangihe, Kotamobagu, Bolmong, Siau, Tawaang and Kendari. From the questionnaire, it is known that the majority of respondents came from the Manado area with a percentage of $47.2 \%$, North Minahasa $13.9 \%$, Minahasa $11.8 \%$ and the rest came from other areas, where the respondent's work varies but is dominated by students as much as $83.3 \%$ of respondents. In addition, there are respondents who work as civil servants, BUMN employees, private employees, entrepreneurs and housewives.

Website media is the best promotional media according to $33.3 \%$ of respondents, followed by Facebook $28.5 \%$, and Instagram $24.3 \%$. And according to $88.2 \%$ of respondents that every tourist attraction must have a website as a promotional medium.

The reason respondents choose the website as an effective tourism promotion tool is because the website as a tourism promotion medium can provide a lot of information needed by tourists in the form of photos, videos and other information

\section{CONCLUSION}

After doing this research, the author can conclude that the development of a website as a tourism promotion medium, especially in Budo Village, can provide convenience for the public to obtain information related to tourism and the potential contained in Budo Village. The effectiveness of the website as a promotional medium is influenced by the completeness of information such as pictures, videos, and other information that describes tourist destinations. In accordance with the results of interviews that have been carried out, that $34 \%$ of people choose the website as an effective medium to promote tourist attractions. In addition, with the existence of this tourist attraction promotion website, there will be an increase in tourist visits which attract other potential visitors so that they can restore tourism sector income in the era of the covid-19 pandemic. This system is designed using the system development method, the RAD (Rapid Application Development) method. thus also allowing for development to improve this system

\section{ACKNOWLEDGMENT}

Thank you to the Manado State Polytechnic for providing the opportunity to carry out research activities as well as providing funding support so that activities can run well.

Thanks are also conveyed to the community and the government of Budo Village as the object of this research.

\section{REFERENCES}

[1] "Strategi Promosi Banyuwangi Sebagai Destinasi Wisata (Studi Kasus Pada Dinas Kebudayaan Dan Pariwisata) | Betari Avinda, Chintiya; Sudiarta, I Nyoman; Oka Karini, Ni Made | download." https://booksc.org/book/72589481/ae7ef5 (accessed Jul. 08, 2021)

[2] T. Kartika, R. Ruskana, and M. I. Fauzi, "Strategi 
Pengembangan Daya Tarik Dago Tea House Sebagai Alternatif Wisata Budaya di Jawa Barat," J. Tour. Hosp. Essent. J., vol. 8, no. 2, Art. no. 2, Nov. 2018, doi: 10.17509/thej.v8i2.13746.

[3] A. Utami, "Analisis strategi promosi online PT.Pusat Media Indonesia," 2011, Accessed: Jul. 08, 2021. [Online]. Available: http://repository.ipb.ac.id/handle/123456789/47639

[4] Wilopo and Hakim, "Strategi Pengembangan Destinasi Pariwisata Budaya." https://docplayer.info/45103350Strategi-pengembangan-destinasi-pariwisata-budayastudi-kasus-pada-kawasan-situs-trowulan-sebagaipariwisata-budaya-unggulan-di-kabupatenmojokerto.html (accessed Jun. 18, 2021).

[5] M. A. S. Kondoj and H. S. Langi, "Design and Implementation of Integrated Information Technology on SME Coconut Oil in North Sulawesi of Indonesia," Int. J. Comput. Appl., vol. 177, no. 7, pp. 18-22, Nov. 2017.

[6] B. Ramadhan, "Data Internet di Indonesia dan Perilakunya Tahun 2020," Medium, Apr. 08, 2020. https://teknoia.com/data-internet-di-indonesia-danperilakunya-880c7bc7cd19 (accessed Jun. 17, 2021).

[7] E. Y. Anggraeni, Pengantar Sistem Informasi. Penerbit Andi.

[8] R. M. Stair and G. W. Reynolds, Principles of information systems: a managerial approach, 9th ed.
Australia; United States: Course Technology Cengage Learning, 2010.

[9] "Sistem informasi manajemen / Raymond Mcleod, Jr. George Schell ; alih bahasa, Hendra Teguh ; penyunting, Agus Widyantoro Sistem informasi manajemen / Raymond Mcleod, Jr. , George Schell; alih bahasa, Hendra Teguh; penyunting, Agus Widyantoro | OPAC Perpustakaan Nasional RI." https://opac.perpusnas.go.id/DetailOpac.aspx?id=508253 (accessed Jul. 08, 2021).

[10] M. Ary, Merancang \& Membuat Website. 2014.

[11] W. Komputer, Belajar membuat blog website berbasis cms dengan wordpress. Accessed: Jun. 18, 2021 [Online]. Available: https://www.academia.edu/31289838/Ebook_belajar_me mbuat_blog_website_berbasis_cms_dengan_wordpress? auto=download

[12] "Secure Sockets Layer and Oracle 11g Security DatabaseJournal.com." https://www.databasejournal.com/features/oracle/article. php/3850106/Secure-Sockets-Layer-and-Oracle-11gSecurity.htm (accessed Jun. 19, 2021).

[13] I. D. D, "Jurnal Metodologi Dan Metode Rapid Application Development (RAD)", Accessed: Jun. 19, 2021. [Online]. Available: https://www.academia.edu/35512347/Jurnal_Metodologi _Dan_Metode_Rapid_Application_Development_Rad_ 